\begin{tabular}{|l|l|l||}
\hline \multicolumn{2}{|c|}{ PublisherInfo } \\
\hline \hline PublisherName & $:$ & BioMed Central \\
\hline \hline PublisherLocation & $:$ & London \\
\hline \hline PublisherImprintName & $:$ & BioMed Central \\
\hline \hline
\end{tabular}

\title{
Rice - the prequel
}

\begin{tabular}{|l|l|l||}
\hline \multicolumn{2}{|c|}{ ArticleInfo } \\
\hline \hline ArticleID & $:$ & 3729 \\
\hline \hline ArticleDOI & $:$ & $10.1186 /$ gb-spotlight-20000719-01 \\
\hline \hline ArticleCitationID & $:$ & spotlight-20000719-01 \\
\hline \hline ArticleSequenceNumber & $:$ & 166 \\
\hline \hline ArticleCategory & $:$ & Research news \\
\hline ArticleFirstPage & $:$ & 1 \\
\hline \hline ArticleLastPage & $:$ & 2 \\
\hline \hline & $:$ & RegistrationDate : 2000-07-19 \\
ArticleHistory & $:$ & OnlineDate \\
\hline \hline ArticleCopyright & $:$ & BioMed Central Ltd2000-07-19 \\
\hline \hline ArticleGrants & $:$ & \\
\hline \hline ArticleContext & $:$ & 130591111 \\
\hline \hline
\end{tabular}




\section{William Wells}

Email: wells@biotext.com

Researchers hoping to decipher the first complete genome sequence of a plant fear the lengthy clusters of repeated transposon sequences present in many plant genomes. But in the July issue of Genome Research, Mao et al. report promising news for the international consortium tackling the rice genome (Genome Res. 2000, 10:982-990). After sequencing 73,000 DNA fragments distributed through the rice genome (a total of nearly $50 \mathrm{Mb}$ ), Mao et al. find that less than $10 \%$ of the sequences contain transposons. Thus transposons should not interfere substantially with the completion of the rice genome sequence. Mao et al. also confirm that transposons called miniature inverted-repeat transposable elements (MITEs) are associated with genes, and thus provide a good way to spot genes in the rice and possibly other plant genomes.

\section{References}

1. Genome research, [http://www.genome.org/] 